\title{
Kantian Categories of Ethics and Morality: A Reading of Milan Kundera's The Unbearable Lightness of Being
}

\author{
Jyotirmoy Prodhani ${ }^{1}$ \\ https://orcid.org/0000-0002-3420-4322 \\ Preetinicha Barman ${ }^{2}$ \\ https://orcid.org/0000-0001-6430-2380 \\ ${ }^{1}$ North-Eastern Hill University, Shillong, India. \\ ${ }^{2}$ Women's College, Shillong, India.
}

\begin{abstract}
Milan Kundera's The Unbearable Lightness of Being is one of the most romantic stories set against a volatile political backdrop wherein the author deals with multiple issues on ideology, ethics and morality. Kant is a foundational thinker in terms of theorizing the notion of morality leading to almost universal categories of moral and ethical imperatives. Kundera's novel quite significantly appears incommensurable to, what we can call as, universal "categories of imperatives." Not only the question of morality but even the categories of ideological imperatives have also been emphatically interrogated by Kundera in the novel. The paper is an attempt to understand the Kantian categories as propounded in his The Critique of Practical Reason and revisit Kundera's novel for a critical engagement to relook at the questions of universal categories of morality as well as ideology. Quite significantly, Kundera uses the term "kitsch" in the novel almost as a discursive tool to counter and denounce the proclamations of the superiority of essentialist political ideology. The novel essentially problematises the Kantian notion of universal morality showing how the universal categories of both morality and reason are inadequate propositions to address the limitless terrains of heterogeneous imperatives.
\end{abstract}

Key Words: Categories of imperatives, morality, ideology, universality, kitsch.

The terms ethics and morality invariably overlap with each other while using them interchangeably in research works (Ellemers), though such elucidation is erroneous. In Blackburn's words "An ethical climate is a different thing from a moralistic one" (3). Ethics is a relational term associated with the social norms or conventional system of a community while morality relates to the individual self (Heath; Everett). The present paper is an attempt to

This open-access work is licensed under a Creative Commons Attribution Noncommercial 4.0 International License. For more information visit https://creativecommons.org/licenses/by-nc/4.0/ 
understand the deeper nuances of ethics and morality in the context of Kundera's novel, The Unbearable Lightness of Being, taking philosophical cues from Kantian standpoints.

Ethics is variously understood as, "science of the ideal involved in human life," "study of right or good in human conduct," "systematic activity of valuing," "normative science" of human conduct in society etc. (Saida 1-2). In this sense, ethics emanates from the collective morality of the majority of the individuals living in a society or a community. The ethical codes or rules, nonetheless, lead to a holistic set of moral judgments which works as normative ethics against which individual morality is judged.

Moral philosophers generally believe that there is more to morality than just these rules; they think that something is underlying them, although they disagree with one another almost entirely about what this might be (...) Nevertheless, they tend to converge in the acknowledgement that there is a body of rules and that these rules in some form are what guide most everyday moral conduct. This suggests that, when it comes to understanding morality, a good place to start might be with trying to form a better understanding of this body of rules - where they come from, how they change, and what motivates people to respect them. (Heath)

Simon Blackburn in his book Being Good underlines the subtle differences between ethical and moralistic climates. Significantly, he would point out that an ethical climate might well be quite hostile to that of moralizing. As he would argue that the central concern of the earlier thinkers of ethics such as the authors of the "Upanishads, or Confucius, or Plato or the founders of the Christian tradition" was the "state of one's soul, meaning, some personal state of justice or harmony" which also requires a "just political order" (4). 
Immanuel Kant in his Groundwork I \& Groundwork II as well as in Critique of Practical Reason (see Russell) talks about morality as a universal entity that has to be attained by the application of a priori reason. This a priori reason does not arise out of any experience. It is a pure faculty felt only by the purely rational ones who must bear the responsibility to induce morality based on this highly precious ability. This active reason emanates from the categories of imperatives which should govern human behaviour and is capable of bringing in the common good. Against the categorical imperatives stand hypothetical imperatives which imply the means to achieve certain goals (Wolemonwu). In contrast, the categorical imperatives do not necessarily aim at attaining or achieving anything. They are ends, not means and hence are free from any expectation (Satkunanandan). The common good that is brought by the categorical imperatives is holistic and the most ethical. Since a priori reason is a cognitive capacity that appeals to the prevalence of this universal ethics, it is supposed to be uniform for all. At the same time, it is independent of any extraneous influence or even metaphysical doctrine (Bojanowski). Rather, a priori reason relates to metaphysics directly and forms practical reason.

The Kantian notion of the common good, however, attempts to settle down the problems and negative impulses through the prospect of this common good while every individual will be benefitted from the mutual consent to follow it. In this context, Kant's theory of practical reason directly implies a practical purpose that is, the prospect of transmitting the common good. This common good, however, has nothing to do with personal happiness. A priori knowledge that brings this common good is applied for the sake of necessity, though this concept of necessity is universal rather than the necessity of the individuals. As Kant believes, since the practical reason does not limit itself to material principles, it is free. In his Groundwork II Kant considers the 
moral principle to be autonomous. It acts as the universal determiner of the will which itself is universal and offers a moral law applicable to one and all.

So, Kant's idea of practical reason seems to claim a homogenized, collective conception that is believed to be shared by every moral being having the capacity to reason. In this sense, individual morality or the morality of self does not figure as a separate entity and rather depends on the universal morality of which it is just a part. Morality, in this case, seems to be similar to the concept of ethics, not in its relativist form, but as the universal determiner of right and wrong. The categorical imperatives that originate from morality aim at good intentions; their success does not depend on practical implementation. Here, the immediate questions that trigger are Can the universal good apply to every individual self irrespective of their inimitable positions? Can moral imperatives apply to every situation while the individual goes through diverse experiences and possess distinctive choices? Is personal happiness a matter of far lesser importance than the universal good? If so, how should one react to an adverse situation when one's happiness is at stake? Can the universal moral law bring justice to one or should one sacrifice one's individualism at the cost of the universal good, as the categorical imperatives presuppose? The idea of autonomy sounds Platonic as autonomy in Kant's theory seems to be quite close to the idea of disinterestedness.

The present paper attempts an enquiry into Kant's notion of morality in terms of the individual self as against universal or social codes of ethics. However, Kant has already been critiqued by several eminent philosophers, from Hegel and Mill to Nietzsche and Bertrand Russell. The paper seeks to look at the problematic nuances of morality and ethics concerning Milan Kundera's work The Unbearable Lightness of Being, which quite significantly problematises the notion of universal morality reflecting how the universal categories of both 
morality and reason are inadequate propositions to address the limitless terrains of heterogeneous imperatives.

Milan Kundera's The Unbearable Lightness of Being, published in 1984, is a novel that deeply problematises the essentialised notions of ethics and morality both in the spheres of private and the public. Tomas is a physician who has divorced his wife almost soon after their first son, Simon, was born. He resumes his promiscuous ventures and eventually quite unintentionally ends up with Tereza with whom, despite his continuous engagements with numerous women, he spends his life till the end. There is another set of characters in the novel, Sabina being one of the most important among them. Sabina, an artist, is the woman Tomas desires but fails to commit fully to her for deep down he feels that Tereza is the most vulnerable one who requires him more than anyone else. Following political turmoil, Tomas and Tereza move to Geneva from Prague. Sabina too comes to Geneva. Tereza comes back to Prague; Tomas, despite his sense of freedom in the absence of Tereza, fails to cope up with the sense of lightness and ends up with Tereza in Prague again. Sabina finds a new beau, Franz, who becomes desperate to finally settle with her at the cost of his family. Sabina on learning that Franz has disclosed their relationship to his wife, Mari-Claude, walks out of the relationship quite unceremoniously leading Franz to share life with one of his young students. It is a story of love and the anxieties of relationship, but Kundera draws deeper recesses to address some of the most fundamental existential questions in the background of enormous political upheavals.

Kundera begins with the notion of the eternal return of Nietzsche which argues for the return of experiences as a model of eternal recurrence. But the eternal return is a terrifying prospect for it might as well, writes Kundera, nail us to eternity as Jesus Christ nailed on the cross. Therefore for Nietzsche, the idea of eternal return is the heaviest of burdens. In that case, 
our life can stand out in splendid lightness. Here Kundera brings in a crucial moral question “"Is heaviness truly deplorable and lightness splendid”? (Kundera 4).

Heaviest of burdens crushes us, pins us to the ground, but in the love poetry of every age, lovers long the weight of their beloved. Thus "the heaviest burden can also be simultaneously an image of life's most intense fulfillment" (Kundera 5). On the other hand, the heavier the burden, the closer one comes to the earth, more truthful and real do they become. The absolute lightness makes a man soar to the sky, makes him distant, "half real," "his movements are as free as they are insignificant" (5). Kundera refers to Parmenides, the sixth-century philosopher who had devised nature in terms of permanent and sensory realities- "What is" and "What not is" ( See Russel). While distinguishing the unity of nature and its variety, Parmenides emphasised the "way of truth" upon the reality of its unity which is eternal, uniform, timeless and unchanging, this is the object of knowledge (The Stanford Encyclopedia of Philosophy). The transitory world of senses is the "way of opinion" which is the world of appearances, the world of variety and unreality. Within his paradigm, the world is divided into binaries, as Kundera would draw light/ darkness, fineness/ coarseness, warmth/ cold, being/non-being as the constant dichotomies. The negative-positive divide seems too simple a moral division between positive and negative. But the similar judgment becomes tricky between lightness and weight. It is equally difficult for the other set of binaries as well. This is where morality takes off as relative exigency. Kundera interrogates Parmenides when he categorised lightness as positive and weight as negative. Kundera would ask, "Was he correct or not? That is the question. The only certainty is: the lightness/ weight opposition is the most mysterious, most ambiguous of all" (5), and so is morality. Georgina Fozard writes in this connection: 
The main characters, Tomas and Sabina (his mistress), are characterised by 'lightness' they don't ally themselves to political parties, traditional morality, a single sexual partner, or even a job role. In comparison, Tomas' long-term girlfriend, Tereza, is a 'heavy' character, she cannot accept the unbearable lightness of being and seeks to attach meaning and 'weight' to what she considers important in life (Fozard 377).

Morality in Kant emerges as an objective that is universal and necessary, symmetrical with the metaphysics of experience which is neither dependent on the empirical facts nor the supersensitive realm of transcendent metaphysics. For Kant morality is higher than human desires and customs. Moral judgment is an exercise in the necessity for it emanates from an order of reason and not from nature (Groundwork I). In Critique of Practical Reason he reinforces this aspect of morality concerning reason that produces it, as, "For reason's legislation, however, it is requisite that reason need presuppose merely itself because the rule [it gives] is objectively and universally valid only when it holds without contingent, subjective conditions, which distinguish one rational being from another" (Kant 32).

What is a moral action? Moral actions are based on principles and not on the anticipation or desire for a result or consequence, for it excludes inclination, therefore it is formal or a priori. Kant assigns the warrant of moral action upon a perfect moral agent who has the inherent knowledge of the morally good will. His actions (the perfect being's) are descriptive in contrast to the human agent whose moral actions are the acts classified as what ought to be. The moral action emanates from dutiful action that presupposes goodwill, which is determined by the principles of a priori. The supreme principle of morality is the capacity to identify this principle of a priori. Kant quite significantly assigns the capacity to identify this supreme principle to a moral agent, the perfect rational being as against the imperfect human agents. A moral agent is 
capable of acting autonomously, who assigns law unto himself. The principle of autonomy in the case of the moral agent is descriptive for his acts entail what he would do and for the human agent it entails what one ought to do. Autonomy is the essence of moral action. A moral agent has the "will" and the "faculty of practical reason" as per the conception of law.

In The Unbearable Lightness of Being there is a deep contrast between individuals as human agents and the state that has gained almost the quasi formidable power to enact as rational agent especially the regime under Russian communists who have occupied Tomas's country, Czechoslovakia. The state becomes a true autonomous moral agent to engulf every aspect of the lives of the citizens, the human agents. The moral penetration of the authorities is so deep that the state under the Russian occupants gains more knowledge on every private and public move of each writer, professional, poet, teacher, editor and all of them who have some measure of worth, much more than they know about their people back in Russia. But the action of the state is following the moral principle of the ideology based on which every act of brutality is justified as sacred interventions. The desire to establish their moral act as essential precursors to universal law effectively eliminates all possibilities of alternative idioms.

Kundera dwells at length to adequately resignify his idiom, kitsch, as an idea to make his critique of the monopoly moral precepts controlled by the narratives of self-induced realities perceived as incongruous to the smooth sheen of the rhythms of totalitarian maxims. Kitsch is a German word associated with sentimental over romantic aesthetics that prefers conscious erasure of many of the basic elements of life. He writes:

Kitsch' is a German word born in the middle of the sentimental nineteenth century, and from German, it entered all Western languages. Repeated use, however, has obliterated its original metaphorical meaning: kitsch is the absolute denial of shit, in both literal and 
figurative sense of the word; kitsch excludes everything from its purview which is essentially unacceptable in human existence (242).

The maxims, in a Kantian sense, are the subjective principle of a rational agent based on objective principles. Sabina in response to the enthusiasm of Franz about the ameliorating capacity of marches silently reflects, "behind Communism, Fascism, behind all occupations and invasions lurks a more basic, pervasive evil and that the image of that evil was a parade of people marching by with raised fists and shouting identical syllables in unison" (Kundera 97). In the frenzy of the parade, the participants are conditioned to remain oblivious of the sinister truth of its flipside that Kitsch excludes everything from its purview which is essentially unacceptable in human existence. Sabina recalls the communist parades during her younger days in which the participants were tricked to raise their fists to celebrate Communism with the conscious pretension as they were celebrating life. The kitsch assumes a pernicious vigour when it degenerates into totalitarian kitsch. According to Kundera, kitsch has dual aspects: it is existential as well as emotional in nature. Kundera exposes the main characters of the novel Tereza, Tomas, Sabina and Franz- who at the same time is also involved in complex emotional and erotic relationships. According to Hudymac, "Kundera's reflection once again touches upon Broch, who understood kitsch as an antithesis of art, its inherent evil, "Antichrist" potential, capable of being activated at any moment" (89).

Sabina's disgust towards Communism as described in the novel was driven by her sense of aesthetics rather than ethics: "Sabina's inner revolt against Communism was aesthetic rather than communal in character. What repelled her was not nearly the ugliness of the communist world (ruined castles transformed into cow sheds) as the mask of it tried to wear- in other wordsCommunist kitsch. The model of Communist kitsch is the ceremony called the May Day" (242). 
Categorical imperatives give rise to an action that is good in itself. It is performed for its own sake for the principles it embodies without any precondition of ends. The state assumes the authority of quasi holy will - the will for which "ought to" is not necessary. Categorical imperative forever eludes the state kitsch for the seemingly moral act that performs though it arrogates itself as simultaneously potential to be a universal law.

Any given set of morality if construed as a category of universal degenerates into kitschfor morality's ethical prediction is its relativism, context specificity. Karenin, the adorable pet dog of Tomas and Tereza is afflicted by cancer. To end his agonizing suffering they decide to inject a sedative because they could resolve a crucial moral crisis: "Dogs do not have many advantages over people, but one of them is extremely important: euthanasia is not forbidden by law in their case; animals have the right to a merciful death" (Kundera 291).

Morality, when degenerates into kitsch become a defeated human enterprise for it only, evokes the longing for Nietzsche's eternal return the impossibility of which engenders our grief primarily because of our misplaced notion about life: "And therein lies the whole of man's plight. Human time does not turn in a circle; it runs ahead in a straight line. That is why man cannot be happy: happiness is the longing for repetition" (Kundera 26).

Hence, morality can never be a metanarrative that can resolve all kinds of incongruities. Universal morality rather sounds illusory when there are so many nuances of justifications. Besides, the concept of the rational man/men who could be the begetter of goodwill appears erroneous. The concept of autonomy arises here when the rational man's a priori, autonomous reason leads him to what he would do and what the rationally imperfect man ought to do. Even 
the universal law that Kant prescribes seems impossible in a heterogeneous world diversely interpreted from different points of view.

Significantly, Simon Blackburn would observe that reflections on ethics are not the "private preserve of a few academic theorists in universities" and the philosophers. For him the satirists, cartoonists, artists, novelists also make perceptive comments on ethics as effectively as those known as philosophers. He would argue that novelists such as Harriet Beecher Stowe, Dickens, Zola, or Solzhenitsyn "may be much greater than that of the academic theorist. A single photograph may have done more to halt the Vietnam War than all the writings of moral philosophers of the time put together" (Hamilton 5-6). Kundera is one such novelist who has kept on redefining the received notions of several abiding ideas and values including the understanding of life itself.

Life, a manifestation of myriad expressions and experiences, is not an absolute pre-given. Life in a moral sense is a predetermined set of codes of practical exigencies where an individual might get frozen in a state of a Nietzschean idea of eternal return what Kundera at the beginning of the novel expresses as his dreadful apprehension. For him, life is an unencumbered celebration of experiences. After all, as Kundera reflects, "What can life be worth if the first rehearsal for life is life itself' (Kundera 30).

\section{Works Cited}

Blackburn, Simon. Being Good: A Short Introduction to Ethics. Oxford UP, 2001

Bojanowski, Jochen. "Kant on the Justification of Moral Principles.” Kant-Studien, Vol. 108, No. 1, 2017, pp. 55-88. https://doi.org/10.1515/kant-2017-0001 
Ellemers, Naomi, Jojanneke van der Toorn, Yavor Paunov, Thed van Leeuwen. "The Psychology of Morality: A Review and Analysis of Empirical Studies Published From 1940 Through 2017.” Personality and Social Psychology Review, Vol. 23 Issue. 4, pp. 332-366. https://doi.org/10.1177/1088868318811759

Everett, Jim A. C. et al. "The moral self and moral duties.” Philosophical Psychology, Vol. 33, Issue 7, 2020, pp. 924-945. https://doi:10.1080/09515089.2020.1789577

Fozard, Georgina. "The Unbearable Lightness of Being a Doctor.” The British Journal of General Practice. Vol. 60, No. 574, 2010, 377. https://doi:10.3399/bjgp10X501967

Hamilton, Christopher. Living Philosophy: Reflections on Life, Meaning and Morality. Edinburgh UP, 2001.

Heath, Joseph. "Morality, convention and conventional morality." Philosophical Explorations. Vol. 20, Issue 3, 2017,pp. 276-293. https://doi.org/10.1080/13869795.2017.1362030.

Hudymac, Aleksandra. "Kundera's Struggle with Kitsch- On the Unbearable Lightness of Being Once Again.” Cultural Studies Appendix - English Issue, 2019. https://zalacznik.uksw.edu.pl/sites/default/files/zalacznik_eng_2019_1.8_Hudymac.pdf

Kant, Immanuel. The Moral Law: Groundwork of the Metaphysics of Morals. 1785. Translated by H.J. Paton. Routledge, 2005

- The Critique of Practical Reason. 1788. Translated by Werner S. Pluhar. Hackett Publishing Company, Inc., 2002.

Kundera, Milan. Unbearable Lightness of Being. Faver and Faver, 1995. 
Midgley, Mary. Utopias, Dolphins and Computers: Problems of Philosophical Plumbing. Routledge, 1996.

Perry, John. and Michael Bratman. Introduction to Philosophy: Classical and Contemporary. Oxford UP, 1986.

Russell, Bertrand. History of Western Philosophy. Routledge, 2009.

Shaida, S.A. Problems of Ethics. Spectrum Publications, 2003

Satkunanandan, Shalini. “The Extraordinary Categorical Imperative.” Political Theory, Vol. 39, No. 2. 2011, pp. 234-260.

The Stanford Encyclopedia of Philosophy. Center for the Study of Language and Information (CSLI), Stanford University, 2008. https://plato.stanford.edu/entries/parmenides/. Accessed 24 June 2021.

Wolemonwu, Victor Chidi \& Chistian Pius Ekpoudom. "The role of reason in Kant's moral philosophy." Sophia: An African Journal of Philosophy. Vol. 15 No. 2, 2015.

\section{Bionote:}

Jyotirmoy Prodhani, PhD, is a Professor in the Dept. of English, North-Eastern Hill University, Shillong. He is the author of the books Creativity and Conflict in the Plays of Sam Shepard; Culture, Ethnicity and Identity: A Reader (co-edited); Madhupur Bahudur (translation of Assamese short stories of Sheelabhadra); This Land This People (translation of Rajbanshi poems with Pradip Acharya). Besides, he has published several research papers in various journals and edited volumes. He can be reached at rajaprodhani@gmail.com (Corresponding Author)

ORCID ID: $\underline{\text { https://orcid.org/0000-0002-3420-4322 }}$

Preetinicha Barman, PhD, is an Assistant Professor of English at Women's College, Shillong. She is the author of the book Orhan Pamuk: A Critical Reading. Besides, she has published 
several book chapters, research papers, book reviews and poems in various journals of repute. Aior Photok is a collection of her Rajbanshi poems.

ORCID ID: https://orcid.org/0000-0001-6430-2380

\section{Open Access:}

This article is distributed under the terms of the Attribution-NonCommercial 4.0 International (CC BY-NC 4.0) (https://creativecommons.org/licenses/by/4.0/) which permits any use, reproduction and distribution of the work without further permission provided the original work is attributed as specified on the Transcript: An e-Journal of Literary and Cultural Studies.

For more information log on to http://thetranscript.in/

\section{Conflict of Interest Declaration:}

The author declared no potential conflicts of interest about the research, authorship and publication of this article.

(C) Authors 